\title{
Molecular Characterization of 28 Mango Germplasm Using RAPD
}

\author{
M. L. Rahman, M. G. Rabbani*, M. N. A. Siddique1, \\ M. A. Rahman, E. J. Garvey ${ }^{2}$ and E. H. M. S. Rahaman ${ }^{3}$ \\ Department of Horticulture, Bangladesh Agricultural University, Mymensingh-2202, \\ Bangladesh \\ Key words: Germplasm, Characterization, Mango, RAPD
}

\begin{abstract}
Genetic variation and relationship among 28 mango germplasm were analyzed using Random Amplified Polymorphic DNA (RAPD). Out of 20 primers screened, four were selected, which gave 50 clear and bright fragments, out of which 48 fragments were considered polymorphic. The proportion of polymorphic loci and gene diversity values across all loci were $96 \%$ and 0.29 , respectively. The UPGMA dendrogram based on genetic distance segregated the 28 mango germplasm into two main clusters. Sukul alone formed one cluster and the rest germplasm were grouped together into another cluster. Mallika and Amrapali cultivar pair was very close to each other with the highest intervarietal similarity index $(87.30 \%)$ and lowest genetic distance $(0.08)$. On the other hand, Sukul and Meghnath pair was more distant to each other with the lowest intervarietal similarity index $(14.29 \%)$ and highest genetic distance $(0.87)$. The results of the present study indicated that the RAPD analysis could be utilized by breeders for further improvement of mango varieties.
\end{abstract}

\section{Introduction}

Mango (Mangifera indica L.) is an important member of the family Anacardiaceae and is believed to have originated in the Indo-Burma region (Popenoe 1927; Mukherjee 1951). It is the most popular fruit among millions of people in the region and is the choicest of all indigenous fruits. Mango ranks first in terms of area in which grown and third in respect of production among the fruits grown in Bangladesh.

Differentiation of cultivars through morphological features is inefficient and inaccurate. This problem is further compounded by the perennial nature of the crop. The use of biochemical and genetic markers for identification of varieties offer a viable alternative method (Williams et al. 1990). At present several mango

${ }^{1}$ Integrated Agriculture Development Project in Greater Sylhet District Including Orange and Pineapple Development, DAE, Sylhet, Bangladesh. Email: mnas_1976@yahoo.com 2USDA/ARS/ NGRL, BARC-west, Beltsville, MD-20705, USA. ${ }^{3}$ CVFB Project, Department of Horticulture, Bangladesh Agricultural University, Mymensingh-2202, Bangladesh. E-mail: shohag72@yahoo.com 
cultivars have many synonyms in different regions which make identification difficult. The efficacy of a selection scheme or genetic analysis based on phenotype is a function of heritability of the trait. Factors like environment, traits of multigenic and quantitative inheritance, or partial and complete dominance often compound the expression of genetic traits. Many of these complications of a phenotype-based assay can be overcome through direct identification of genotype with DNA-based genetic markers.

Polymerase Chain Reaction (PCR) technology had led to the development of several novel genetic assays based on selective DNA amplification. The protocol is also relatively quick and easy to perform. Because the RAPD technique is an amplification-based assay, only nanogram quantities of DNA are required. One of the strengths of these new assays is that they are more amenable to automation than conventional techniques. It is simple to perform and is preferable to experiments where the genotypes of a large number of individuals are to be determined at a few genetic loci. With this idea the experiment was undertaken to evaluate genetic variation and relationships of some mango cultivars by RAPD technique.

\section{Materials and Methods}

Twenty eight mango germplasm were used in this study. In order to carry out RAPD analysis, mature leaves from each of the 28 germplasm were collected randomly from different parts of Bangladesh. Total genomic DNA was isolated from mango leaves following phenol : chloroform : isoamyl alcohol purification and ethanol precipitation method. Finally, the DNA samples were stored at - $20^{\circ} \mathrm{C}$. DNA concentrations were determined at $260 \mathrm{~nm}$ spectrophotometrically and the quality verified by electrophoresis on a $1 \%$ agarose gel.

DNA amplification was done using four arbitrary decamer primers (Operon Technologies, Inc., Alameda, California, USA OPA-07, OPA-11, OPC-12 and OPC-13) adopting the procedure of Williams et al. (1990) with some modifications. PCR reactions were performed on each DNA sample in a $10 \mu \mathrm{l}$ reaction mix containing $1 \mu \mathrm{l} \mathrm{Taq}$ polymerase buffer $(10 \times)$, $2.5 \mu \mathrm{l}$ primer $(10 \mu \mathrm{M})$, $1 \mu \mathrm{l}$ dNTPs $(250 \mu \mathrm{M}), 1$ unit Taq polymerase, $4 \mu \mathrm{l}(100 \mathrm{ng})$ genomic DNA (25 $\mathrm{ng} / \mu \mathrm{l}$ ) and rest amount of sterile deionized water to prepare $10 \mu \mathrm{l}$ reaction mixtures. DNA amplification was performed in an oil-free thermal cycler (Master Cycler Gradient, Eppendorf). The reaction mix was preheated at $94^{\circ} \mathrm{C}$ for three minutes followed by 45 cycles of one min denaturation at $94^{\circ} \mathrm{C}$ one min annealing at $35^{\circ} \mathrm{C}$ and elongation or extension at $72^{\circ} \mathrm{C}$ for two minutes. After the last cycle, a final step of seven minutes at $72^{\circ} \mathrm{C}$ was added to allow complete extension of all amplified fragments. After completion of cycling programme, reactions were held at $4^{\circ} \mathrm{C}$. The amplified products were separated 
electrophoretically on a $1.4 \%$ agarose gel. Two molecular weight marker, pUC and $100 \mathrm{bp}$ DNA ladder were electrophoresed alongside the RAPD reactions. Electrophoresis was carried out at $90 \mathrm{~V}$ for $1 \mathrm{~h}$ and 15 minutes. DNA bands were observed under UV light on a Transilluminator and photographed.

Since RAPD markers are dominant, we assumed that each band represented the phenotype at a single allelic locus (Williams et al. 1990). All distinct bands or fragments (RAPD markers) were thereby given identification numbers according to their position on gel and scored visually on the basis of their presence (1) or absence (0), separately for each individual and each primer. The scores obtained using all the primers in the RAPD analysis were then pooled to create a single data matrix and used to estimate polymorphic loci, gene diversity, genetic distance (D) and to construct a UPGMA (Unweighted Pair Group Method of Arithmetic Means) dendrogram among populations using a computer program, POPGENE (Version 1.31) (Yeh et al. 1999).

Genetic similarity values defined as the fraction of shared bands between the RAPD profiles of any two individuals on the same gel were calculated manually from RAPD markers of the same molecular weight on the data matrix according to the following formula:

$$
\text { Similarity index }(\mathrm{SI})=2 \mathrm{~N}_{\mathrm{xy}} / \mathrm{N}_{\mathrm{x}}+\mathrm{N}_{\mathrm{y}}
$$

where, $\mathrm{N}_{\mathrm{xy}}$ is the number of RAPD bands shared by individuals $\mathrm{x}$ and $\mathrm{y}$ respectively, and $\mathrm{N}_{\mathrm{x}}$ and $\mathrm{N}_{\mathrm{y}}$ are the number of bands in individual $\times$ and $\mathrm{y}$, respectively (Chapco et al. 1992, Wilde et al. 1992, Lynch 1990).

\section{Results and Discussion}

The four primers generated 50 bands with size ranging from $105-1500 \mathrm{bp}$. Out of the 50 bands, 48 scorable bands (96\%) were found to be polymorphic and 2 bands $(4 \%)$ were found to be monomorphic. In a previous study LopezValenzuela et al. (1997) reported 74\% RAPD bands as polymorphic among 15 mango cultivars from Mexico, Philippines and Florida. Ravishankar et al. (2000) reported about $73 \%$ RAPD polymorphism (130 polymorphic bands out of total $178)$ in the 18 Indian mango cultivars they studied. The four different primers generated various banding patterns, ranging from 10 to 14 . The primer OPA-07 produced the highest number of polymorphic bands (14). Thus it showed a higher level of polymorphism. On the other hand, the primer OPA-11, OPC-12 and OPC-13 generated 11, 13 and 10 polymorphic bands, respectively. These results gave an average of 12 polymorphic bands per primer (Table 1). The banding patterns of 28 mango germplasm using primers OPA-11 are shown in Fig. 1. 
Kumar et al. (2001) reported Jaccard's similarity in the range of 61 to $95 \%$ whereas similarity in the 28 mango germplasm (Sij) ranged from 14.29 to $87.30 \%$. Obviously, the present material was genetically more diverse than that used by the above workers. Pair-wise comparison of DNA profiles of the 28 mango germplasm showed inter-cultivar similarity indices for Mallika vs. Amrapali (87.30) and seedless mango vs. Amrapali (87.18) which were comparatively higher than all other cultivar pairs. On the other hand, inter-cultivar similarity index for Sukul vs. Meghnath (14.29\%) cultivar pair was comparatively lower than all the other cultivar pairs.

Table 1. RAPD primers with corresponding bands scored and their size range together with polymorphic bands observed in 28 mango germplasm.

\begin{tabular}{ccccccc}
\hline $\begin{array}{c}\text { Sl. } \\
\text { No. }\end{array}$ & $\begin{array}{c}\text { Primer } \\
\text { codes }\end{array}$ & $\begin{array}{c}\text { Total no. of } \\
\text { bands scored }\end{array}$ & $\begin{array}{c}\text { Size ranges } \\
\text { (bp) }\end{array}$ & $\begin{array}{c}\text { Number of } \\
\text { monomorphic } \\
\text { bands }\end{array}$ & $\begin{array}{c}\text { Number of } \\
\text { polymorphic } \\
\text { bands }\end{array}$ & $\begin{array}{c}\text { Proportion of } \\
\text { polymorphic } \\
\text { loci (\%) }\end{array}$ \\
\hline 1 & OPA-07 & 14 & $105-1500$ & 0 & 14 & 100 \\
2 & OPA-11 & 13 & $105-1444$ & 2 & 11 & 84 \\
3 & OPC-12 & 13 & $105-1444$ & 0 & 13 & 100 \\
4 & OPC-13 & 10 & $153-1444$ & 0 & 10 & 100 \\
\hline & Total & 50 & & 2 & 48 & 384 \\
& Average & 12.5 & & 0.5 & 12 & 96 \\
\hline
\end{tabular}

Dendrogram based on Nei's (1972) genetic distance Unweighted Pair Group Method of Arithmetic Means (UPGMA) indicated segregation of the 28 mango germplasm into two main clusters. Sukul alone formed cluster I and rest 27 mango germplasm grouped together in cluster II (Fig. 2.). In cluster II Gopalbhog alone formed sub cluster I and rest 26 mango germplasm grouped together in sub cluster II. Again, in sub cluster II Kishanbhog, Misrikanta, Nagfazli, Ratna, Sindhu, Khirsapath, Kobhupasand, Carabao, McDonald, Hybrid-10 and Pairi grouped together in sub-sub cluster I. Ratna and Sindhu were closely clustered in sub-sub cluster I to their common parent, 'Alphonso'. On the other hand, Ashwina, Bishnu, Dhuma, Kalua, Baneshan, Aruna, Pahari, Horidoshy, Hybrid13, Mallika, Amrapali, Seedless mango, Begontoli, Meghnath and Dulabhog grouped together in sub-sub cluster II. Aruna and Baneshan were closely clustered in sub-sub cluster II because, Aruna is a hybrid between Baneshan and Alphonso.

In sub-sub cluster I Misrikanta vs. Nagfazli; Kobhupasand vs. Carabao and Hybrid 10 vs. Pairi grouped separately with lower level of genetic distance 0.11, 0.17 and 0.20 , respectively.

In sub-sub cluster II Dulabhog alone formed one group. On the other hand Ashwina vs. Bishnu; Dhuma vs. Kalua; Horidoshy vs. Hybrid13 and Mallika vs. Amrapali grouped separately with lower level of genetic distance 0.20, 0.13, 0.15 and 0.08 , respectively. 
Mallika vs. Amrapali cultivar pair very closely clustered to each other because, 'Amrapali' has been developed through selection from a cross between 'Dashehari' and 'Neelum', while the reverse cross has yielded 'Mallika'. Thus,

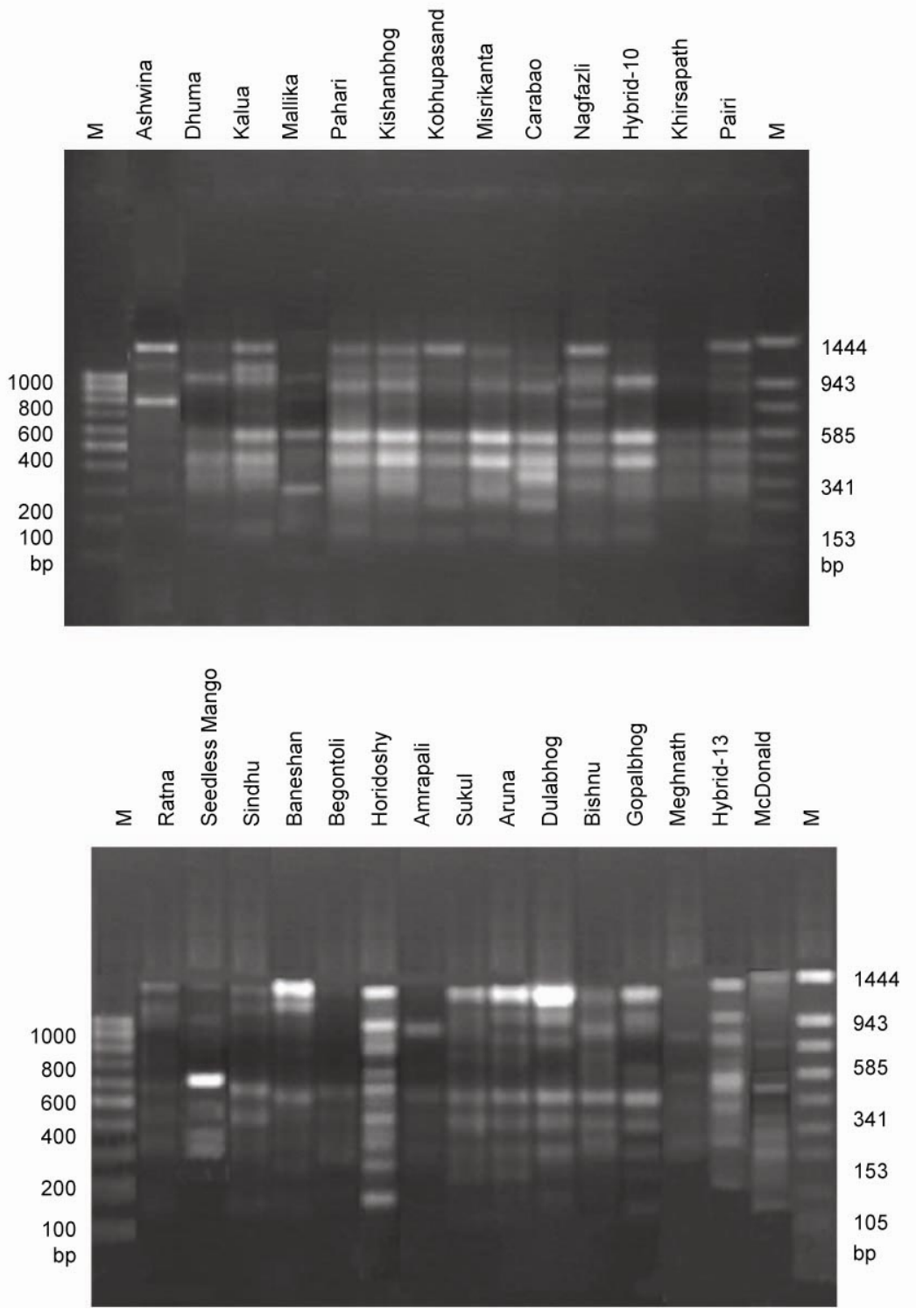

Fig. 1. RAPD profiles of 28 mango germplasm using Primer OPA-11. M: Molecular weight marker (100 bp DNA ladder in left side and pUC in right side).

the hybrids showed greater genetic similarity with 'Neelum' irrespective of whether the latter has been used as the male or the female parent. Available morphological descriptions of the present hybrids indicate that, in addition to a few unique features, they bear characters found in one or the other parent. 
Regular bearing habit is the one distinct feature of 'Neelum' that is shared by both hybrids.

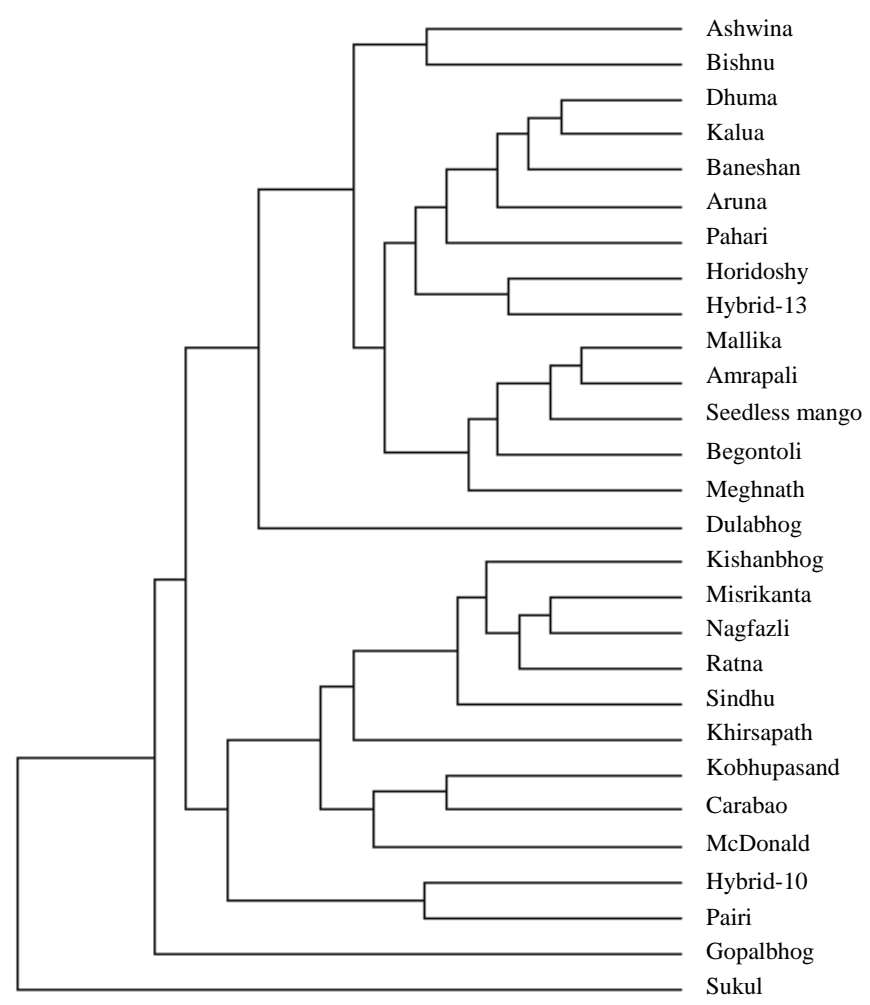

Fig. 2. UPGMA dendrogram besed on Nei's (1972) genetic distance of 28 mango germplasm constructed by cluster analysis of RAPD markers.

The result of the present study indicated that RAPD can be used for identification of the available mango germplasm and their natural parents in Bangladesh. It can also be used to study relationship of the mango germplasm among each other for further improvement through cross-breeding.

\section{Acknowledgement}

The authors wish to acknowledge the authorities of the project "collection, evaluation, conservation and utilization of land races and wild relatives of some important vegetables and fruits of Bangladesh" funded by USDA for providing experimental materials and necessary facilities to conduct the present study. 


\section{References}

Chapco W, Ashton NW, Martel RK, Antonishishyn N and Crosby WL (1992) A feasibility study on the use of random amplified polymorphic DNA in the population genetics and systematic of grasshoppers. Genome. 35: 569-574.

Kumar NVH, Narayanaswamy P, Prasad DT, Mukunda GK and Sondur SN (2001) Estimation of genetic diversity of commercial mango (Mangifera indica L.) cultivars using RAPD markers. J. Hort. Sci. Biotech. 76(5): 529-533.

Lopez-Valenzuela, JA, Martinez O and Pardes OL (1997) Geographic differentiation and embryo type identification in Mangifera indica L. cultivars using RAPD markers. HortScience, 32: 1105-1108.

Lynch M (1990) The similarity index and DNA fingerprinting. Mol. Biol. Evol. 7(5): 478484.

Mukherjee SK (1951) The origin of mango. Indian J. Genet. 2: 49.

Nei M (1972) Genetic distance between populations. Amer. Nat. 106: 283-292.

Popenoe W (1927) Manual of Tropical and Sub-tropical Fruits. McMillan, New York, USA.

Ravishankar, KV, Lalitha A, Dinesh MR and Anand L (2000) Assessment of genetic relatedness among mango cultivars of India using RAPD markers. J. Hort. Sci. Biotech., 75(2): 198-201.

Wilde J, Waugh R and Powell W (1992) Genetic fingerprinting of Theobroma clones using randomly amplified polymorphic DNA markers. Theor. Appl. Genet. 83: 871877.

Williams JGK, Kubelic AR, Livak KJ, Rafalski JA and Tingey SV (1990) DNA polymorphisms amplified by arbitrary primers are useful as genetic markers. Nucleic Acids Res. 18(22): 6531-6535.

Yeh F, Yang C, Boyle TBJ, Ye ZH and Mao JX (1999) POPGENE, the user-friendly shareware for population genetic analysis. Molecular Biology and Biotechnology Centre, University of Albetra, Canada. (http:/ / www.ualbetra.ca/ fyeh). 